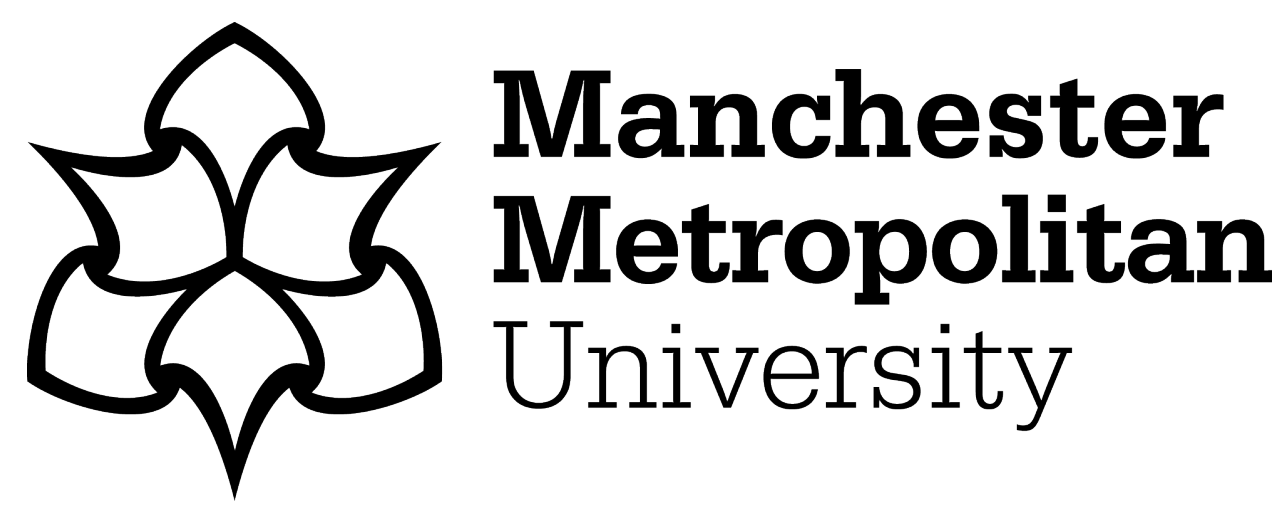

Adshead, Julie (2018) The Application and Development of the Polluter-Pays Principle across Jurisdictions in Liability for Marine Oil Pollution: The Tales of the 'Erika' and the 'Prestige'. Journal of Environmental Law, 30 (3). pp. 425-451. ISSN 0952-8873

Downloaded from: https://e-space.mmu.ac.uk/622003/

Version: Accepted Version

Publisher: Oxford University Press (OUP)

DOI: https://doi.org/10.1093/jel/eqy020

Please cite the published version 


\title{
The Application and Development of the Polluter-Pays Principle across Jurisdictions in Liability for Marine Oil Pollution: The Tales of the 'Erika' and the 'Prestige'
}

\author{
Julie Adshead*
}

\begin{abstract}
This article charts the application and development of the Polluter-Pays Principle (PPP) in one sphere of international law (civil liability for accidental marine oil pollution); a liability regime, very much grounded in its own traditions, which often interacts uncomfortably with national and regional law. The article explores the application of the principle at international, regional and national levels, using the demise of the vessels 'Erika' and 'Prestige' and the case law flowing from the subsequent environmental disasters to illustrate how the principle has developed in this area of international law and how this has the potential to influence its development in other jurisdictions.

KEYWORDS: oil pollution, 'Erika', 'Prestige', Polluter-Pays Principle, liability, environmental damage
\end{abstract}

\section{INTRODUCTION}

Environmental principles have been heralded as bringing much to environmental law and this has been well-discussed elsewhere. ${ }^{1}$ Likewise, there is rich literature surrounding the Polluter-Pays Principle (PPP) and its function in both economic and legal terms. Some of the literature is referred to briefly for contextual purposes at relevant points in the discussion that follows. However, regardless of any conclusions on the debate over the normative function of the PPP (or, indeed, of environmental principles more broadly), as Scotford points out, these principles are developing in individual jurisdictions and often in different directions. ${ }^{2}$ This article focuses upon how the PPP has developed in a sub-set of international law along with specific jurisdictions affected by oil pollution incidents. It recognises the tensions that flow from the interaction between different manifestations of the principle and the potential for

* Manchester Metropolitan University (j.adshead@mmu.ac.uk).

1 Eloise Scotford, Environmental Principles and the Evolution of Environmental Law (Hart Publishing 2017) $37-50$, provides an excellent account of the ways in which environmental principles interact with environmental law with comprehensive reference to the literature.

2 ibid 4, 5, 263. 
its development to be influenced by that interaction. There may not be a single legal formulation of the principle at an international level that filters down to state or regional level, ${ }^{3}$ but what can be seen from this analysis is that the PPP is not developing in a vacuum in separate jurisdictions and there is the potential for its form to be influenced where norms collide.

The first section of the article focuses on the PPP, giving some contextual background, with brief reference to the wealth of literature on environmental principles and the PPP itself. This is followed by some discussion on specific, contested elements of the principle which play out in the cases to be examined; the nature of liability, identification of the polluter, and the kind of damage to be compensated. The second part examines the international regime for civil liability in marine oil pollution accidents. An overview of the features of the regime relevant to the discussion is provided along with some detail on its development and the role of private interests in reaching a mutually acceptable agreement on liability. The final section of the article concentrates upon the 'Erika' and the 'Prestige'. The individual incidents and the subsequent environmental damage along with the complex web of interests involved in each of the shipments provide the backdrop. The discussion then turns to the case law flowing from these two incidents, which both spans jurisdictions and covers a substantial time. ${ }^{4}$ As noted by Scotford, the courts play a critical role in developing environmental law principles and in helping to crystallise their legal potential within discrete legal systems. ${ }^{5}$ The key cases are considered in this final section of the article, concluding with an analysis of the consequence of these cases for the development of the PPP.

It has been argued that the PPP cannot find legal form until it has conceptual and definitional certainty. ${ }^{6}$ This analysis demonstrates the impossibility of reaching the goal of such certainties. For example, there can be no overarching formula for determining who is responsible for and should pay for pollution when the circumstances surrounding polluting incidents differ so widely. No doubt the principle will continue to develop in different directions in separate jurisdictions, but this analysis demonstrates how that development might be influenced across jurisdictions; horizontally and vertically, both 'bottom up' and 'top down'.

\section{ENVIRONMENTAL PRINCIPLES}

It is not the purpose of this article to consider environmental principles in any broad sense. There is no intention to assess their function in environmental law or their

3 ibid.

4 The 'Erika' sank in 2000 and the 'Prestige' in 2002. The most recent respective judgments were delivered in 2012 and 2016.

5 Scotford (n 1) 260. See also, Arne Bleeker, 'Does the Polluter Pay? The Polluter-Pays Principle in the Case Law of the European Court of Justice' (2009) 18 EEELR 289, 293. The crucial role of the judiciary in this respect was noted by Klaus Toepfer, 'UNEP Global Judges Programme' (2005) v < http://wedocs. unep.org/bitstream/handle/20.500.11822/8406/-UNEP\%20Global\%20Judges\%20Programme-20053747. pdf? sequence $=3$ \&isAllowed $=y>$ accessed 14 June 2018 .

6 Patricia Birnie, Alan Boyle and Catherine Redgwell, International Law and the Environment (3rd edn, OUP 2009) 326. See also, the discussion by Scotford (n 1) 51-65. 
limitations in a legal context. These questions have been well-addressed elsewhere, ${ }^{7}$ most recently by Scotford. ${ }^{8}$ She concludes that environmental principles do not generally give rise to high level transnational legal norms. ${ }^{9}$ Having no legal history or clear conceptual identity, Scotford argues that the context in which such principles are applied is important. She suggests that emerging legal meaning can be drawn from the application and development of principles in different legal systems. ${ }^{10}$ This article seeks to investigate this proposition within the specific context of the PPP and liability for marine oil pollution, but also suggests that there is the potential for the development of principles to be subject to cross-jurisdictional influence when international, regional and national law interact.

\subsection{The PPP}

As with environmental principles generally, there is a great wealth of literature on both the economic and legal form of the PPP. ${ }^{11}$ The PPP can be traced back in history to Plato, ${ }^{12}$ but its more modern incarnation has its roots in economic theory, specifically Pigou's proposition that external costs (or externalities) should be internalised. If such costs are hidden, then the market becomes distorted and inefficient economic choices will be made. ${ }^{13}$ In environmental terms, this economic rule requires the polluter to absorb external costs flowing from his/her polluting

7 There is extensive literature. For example: Nicolas de Sadeleer, Environmental Principles: From Political Slogans to Legal Rules (OUP 2002); Richard Macrory, Ian Havercroft and Ray Purdy (eds), Principles of European Environmental Law (Europa Law Publishing 2004); Maurice Sheridan and Luc Lavrysen (eds), Environmental Law Principles in Practice (Bruylant 2002); Michael Doherty, 'Hard Cases and Environmental Principles: An Aid to Interpretation?' (2004) 3 YEEL 57; Gerd Winter, 'The Legal Nature of Environmental Principles in International, EC and German Law' in Richard Macrory, Ian Havercroft and Ray Purdy (eds), Principles of European Environmental Law (Europa Law Publishing 2004); Stephen Tromans, 'High Talk and Low Cunning: Putting Environmental Principles into Legal Practice' [1995] JPEL 779; Elizabeth Fisher, Bettina Lange and Eloise Scotford, Environmental Law: Text, Cases and Materials (OUP 2013) ch 11; Piet Gillhuis, 'The Consequences of Introducing Environmental Law Principles in National Law' in Maurice Sheridan and Luc Lavrysen (eds), Environmental Law Principles in Practice (Bruylant 2002).

8 Scotford (n 1) ch 2 .

9 ibid.

10 ibid 66.

11 For example: Sanford Gaines, 'The Polluter Pays Principle: From Economic Equity to Environmental Ethos' (1991) 26 Texas Int'l LJ 463; Martin O’Connor, 'The Internalization of Environmental Costs: Implementing the Polluter Pays Principle in the European Union' (1997) 7 Int J Env Pollut 450; Aviel Verbruggen, 'Preparing the Design of Robust Civil Liability Policy Architectures' (2011) 11 Int Env Agree 275; Irina Glazyrina, Vasiliy Glazyrine and Sergey Vinnichenko, 'The Polluter Pays Principle and Potential Conflicts in Society' (2006) 59 Ecol Econ 5 324; A Mitchell Polinsky, 'Strict Liability vs. Negligence in a Market Setting' (1980) 70 AER 363; John Dales, Pollution, Property and Prices: An Essay In Policy-making and Economics (Edward Elgar 2002); Allen Kneese and others, Economics and the Environment: A Materials Balance Approach (RFF Press 1970); Henri Smets, 'The Polluter Pays Principle in the Early 1990s' in Luigi Campiglio and others (eds), The Environment after Rio: International Law and Economics (Graham \& Trotman/Martinus Nijhoff 1994); Anthony Heyes (ed), The Law and Economics of the Environment (Edward Elgar 2001).

12 Benjamin Jowett (tr), The Dialogues of Plato: Vol. 4 Laws \& Index to Writings of Plato (OUP 1953) book $8, \mathrm{~s} 485 \mathrm{e}$ 'If anyone intentionally spoils the water of another. . let him not only pay damages but purify the stream or cistern which contains the water.'

13 Arthur Pigou, The Economics of Welfare (2nd edn, Macmillan 1924). The Pigovian theory was subsequently criticised, not least by Ronald Coase, 'The Problem of Social Cost' (1960) 3 J L Econ 1. 
activities. No such costs should be passed on to the state or the public. ${ }^{14}$ Although its origins lie in the economic theory of externalities, the PPP has developed to become a key cornerstone of environmental law and policy. Its emergence as a guiding principle of environmental law has solid European foundations. It was first adopted in 1972 by the Organisation for Economic Co-operation and Development (OECD). ${ }^{15}$ However, early formulations of the principle did not require the polluter to internalise all environmental costs, only those necessary 'to ensure that the environment is in an acceptable state. ${ }^{16}$ Over time, however, formulations of the PPP have moved towards full internalisation of the costs of polluting activities. ${ }^{17}$

The European Union (EU) has closely followed the OECD in the adoption of the PPP. The principle was first articulated in the Environmental Action Programme of 1973 and procedures for its application were set out in Recommendation 75/436. ${ }^{18}$ The PPP now appears in the Treaty on the Functioning of the European Union at Article 191(2), which places an obligation upon the EU institutions to base environmental policy upon the PPP. The early framing of the PPP very much reflected its roots in economic theory. To begin with the OECD and the EU clearly saw the principle as a way of preventing distortion of competition, ensuring a level playing field and attaining a fully functional single market. ${ }^{19}$ However, as the principle developed, it took on redistributive, preventative, and restorative features. ${ }^{20}$ Rather than merely focusing on trade distortions, the PPP began to be linked with incentives for environmental improvements. ${ }^{21}$ Its dissuasive value was recognised, ${ }^{22}$ along with its role as a complement to the principle of prevention. ${ }^{23}$ An understanding that the principle could underpin compensatory and restorative actions as well as funding public authority pollution expenses also evolved over time. ${ }^{24}$

At an international level, the PPP was incorporated into Agenda 21 and the Rio Declaration on Environment and Development ${ }^{25}$ in 1992 but these are particularly soft formulations, containing no state obligation and being couched in the caveats of public interest, trade and investment. ${ }^{26}$ Despite the PPP having been referred to as a

14 de Sadeleer (n 7) 21.

15 OECD, OECD Council Recommendation on Guiding Principles concerning International Aspects of Environmental Policies C(72) 128 (final), (1972).

16 ibid, Annex A (a) (4) and OECD, OECD Council Recommendation on the Implementation of the polluter-pays principle C(74) 223 (final), (1974).

17 OECD, OECD Council Recommendation on the Application of the Polluter-pays Principle to Accidental Pollution C(89) 88 (final), (1989); OECD, OECD Council Recommendation on the Uses of Economic Instruments in Environmental Policy C (90) 177 (final), (1991); de Sadeleer (n 7).

18 75/436/Euratom, ECSC, EEC: Council Recommendation of 3 March 1975 regarding cost allocation and action by public authorities on environmental matters [1975] OJ L194/1.

19 de Sadeleer (n 7) 34; Birnie, Boyle and Redgwell (n 6) 92.

20 de Sadeleer (n 7 ) 35-37.

21 The Third EC Environmental Action Programme (EAP 3) 1982-86.

22 de Sadeleer (n 7) 35-37.

23 ibid 36.

24 Directive 2004/35/CE of the European Parliament and of the Council of 21 April 2004 on Environmental Liability with Regard to the Prevention and Remedying of Environmental Damage [2004] OJ L143/56 (The Environmental Liability Directive).

25 Report of the UN Conference on Environment and Development (Rio de Janeiro, 3-14 June 1992) A/ CONF.151/26 (vol 1) 12 August 1992, Annex 1, Principle 16 and Agenda 21, paras 2.14 and 30.3. Alan Boyle and David Freestone, International Law and Sustainable Development (OUP 1999) 4. 
general principle of international environmental law, ${ }^{27}$ as most of the binding provisions incorporating the PPP are in relatively recent instruments at a regional level, it is doubtful whether the principle constitutes a rule of customary international law. ${ }^{28}$

\subsection{Who are the Polluters and What Should They Pay?}

Pollution incidents often involve a complex web of actors responsible for damage and a key question surrounds how the PPP is satisfied in terms of the division of liability between the responsible parties. One solution is to focus liability upon a single polluter as the person holding overarching responsibility. This certainly simplifies matters on an administrative level ${ }^{29}$ and it is this kind of channelling of liability, which is applied in the international regime for oil pollution liability. Recommendation 75/436 appears to reflect this approach, requiring the costs of pollution to be met 'at the point at which the number of economic operators is least and control is easiest. ${ }^{30}$ Joint and several liability, as an option, will often result in the most solvent of the responsible parties meeting the bulk of the cost. ${ }^{31}$ This 'deep pocket' approach has more recently been criticised by the EU Commission as relying upon the party with the greatest financial resources rather than that which caused the greatest amount of damage. ${ }^{32}$ Allocation of financial responsibility raises a real dilemma in the application of the PPP. The channelling of liability will often result in someone other than the polluter paying. For example, in marine pollution cases, the shipowner is liable regardless of fault, which might lie with the charterer or the cargo owner. Likewise, a disproportionate level of liability may be met by one of a number of polluters under a system of joint and several liability. In a perfect world, each responsible party would meet the full costs of their contribution to the polluting incident but determining such a contribution in the first place and recovering from each liable party in the second are both fraught with difficulties. Is it preferable, in terms of the PPP, that at least most of the costs are met and the victims compensated accordingly or that a large part of the damage goes unaddressed? The latter outcome falls yet further away from meeting the full internalisation of costs ideal and nor will it yield the optimum results for repairing environmental damage.

The discussion so far has centred upon actors directly involved in the pollution incident but what of those responsible by virtue of their activities at an industry level? This is a particularly pertinent question in the case of the international oil pollution regime where the secondary level of compensation derives from oil producers. The PPP, as discussed above, would seem to indicate that there is no place for responsibility outside of the individuals or state directly involved in the incident. However, in the case of global activities, which threaten shared environmental resources such as climate and the marine environment, should the polluter be

27 Protocol on Preparedness, Response, and Co-Operation to Pollution Incidents by Hazardous and Noxious Substances (OPRC-HNS Protocol, IMO, London) adopted 15 March 2000.

28 Philippe Sands and Jacqueline Peel, Principles of International Environmental Law (4th edn, CUP 2018) 240; Philippe Sands, Principles of International Law (Manchester UP 1995) 213.

29 de Sadeleer (n 7) 41.

30 See n 18, Annex, art 3.

31 de Sadeleer (n 7) 53.

32 European Commission, 'White Paper on Environmental Liability' (2000) COM (2000) 66 final. 
conceptualised at a more global level? For example, in the case of oil pollution incidents, should the world's major oil companies have some overarching responsibility? There is surely a compelling argument that undertaking the high-risk activity of transporting highly polluting substances by sea brings the oil producers within the ambit of 'polluter' for the purposes of the principle when oil spills occur. This is particularly the case when considering the way in which the shipping industry has traditionally operated, using 'shell' companies and transporting heavy fuel oils in aged and substandard vessels. ${ }^{33}$

A more radical interpretation of the principle flows from a different conception of the polluter. At a time when there is a clear imperative to reduce our reliance upon fossil fuels, it can be argued that our individual choices in supporting and sustaining the oil industry lay us open to liability when things go wrong and environmental damage ensues. Thus, the consumers, whose interests are served by the high-risk transportation of oil, can be seen as the root polluters. This is picked up by the OECD, in a 'User Pays Principle' to complement the PPP. ${ }^{34}$ The same inherent logic of internalisation of external costs applies ${ }^{35}$ and, furthermore, the 'User Pays Principle' serves the overarching goal of sustainable development. ${ }^{36}$ The formulations of the PPP in German and Swiss law, ${ }^{37}$ which make no specific reference to the polluter, align with a broader conceptualisation of the principle. This can be expanded yet further to embrace social damages arising from pollution and this has been referred to as the 'Extended Polluter Pays Principle'. ${ }^{38}$ If the argument for a broader conceptualisation of the PPP is accepted, then states picking up residual responsibility for damage, which is then passed on to the tax payer sits more comfortably with the principle.

The PPP is silent on what constitutes damage and it is here that one of the contentious issues around the principle arises. The debate surrounds the question of whether the polluter should pay for pure environmental damage. ${ }^{39}$ Pure environmental damage or environmental damage per se is that to which no direct financial cost accrues to an individual or state and this may include compensation for lost natural

33 Jose Juste-Ruiz, 'Compensation for Pollution Damage Caused by Oil Tanker Accidents: From "Erika” to "Prestige”' (2010) 1 Agean RL Sea 38.

34 OECD, OECD Council Recommendation of 31 March 1989 Concerning the Management of Aquatic Resources: integration, demand management and protection of groundwaters, C(89) 12 (final) (1989); OECD, OECD Council Recommendation of 31 March 1991 Concerning the Use of Economic Instruments in Environmental Policy, C(90) 177 (final) (1991); OECD, OECD Council Recommendation of 23 July 1992 on the Integrated Management of Coastal Zones, C(92) 114 (final) (1992).

35 de Sadeleer (n 7) 42.

36 ibid.

37 Verursacherprinzip and principe de causalite respectively. The principle is enshrined in art 1382 of the French Civil code and an example in German Law can be found in art 8 of the Federal Nature Protection Act/Bundesnaturschautzgesetz (BNSchG).

38 John Pezzey, 'Market Mechanisms of Pollution Control: “Polluter-pays”, Economic and Practical Aspects' in R Kerry Turner (ed), Sustainable Environmental Management: Principles and Practice (Westview 1988) 190.

39 Peter Wetterstein, 'Trends in Maritime Environmental Impairment Liability' [1994] LMCLQ 230; Louise de La Fayette, 'New Approaches for Addressing Damage to the Marine Environment' (2005) 20 IJMCL 167. 
resources. Damage of this sort does not fit easily within the traditional legal framework for liability as the 'victim' is the environment and there is, therefore, no individual to compensate. ${ }^{40}$ Furthermore, there are self-evident problems in putting a value on pure environmental damage, particularly when an environment or species is eliminated and is irreplaceable. In such cases consideration and calculation of intrinsic value is necessary. Even if such a valuation is possible, questions surround who should be the recipient of damages in such cases. However, if reparation is not made for degradation and loss of environment, then the spirit of the PPP is not met, nor are costs fully internalised. There has been some shift towards recognising pure environmental damage in the EU. ${ }^{41}$ Nonetheless, other than in the USA, ${ }^{42}$ liability for environmental damage per se is not widely embraced and there are few provisions at an international level that recognise the concept. ${ }^{43}$

\subsection{Strict Liability under the PPP}

A related debate surrounds whether liability in application of the principle should be strict. If one accepts the narrower formulation of the PPP and that only the person or entity responsible for the pollution should pay, then there is an argument flowing from this that only an operator who is at fault in terms of the polluting incident should be liable. Following this argument, in the example of an oil pollution incident, a shipowner would only be liable if responsible for the root cause of the accident. If the accident was caused, eg by the charterer, then they would be liable. ${ }^{44}$ However, proving fault is notoriously difficult and time consuming and may lead to problems in allocation of liability and hence inadequate compensation for damage and a subsequent failure to internalise costs. Also, there is an argument that operators engaged in high-risk activity should bear the risk of liability regardless of fault. Certainly, there are a good number of environmental damage regimes, which support and apply strict liability. ${ }^{45}$ Taking a broader perspective of the principle and looking to its essence of passing the whole cost of the damage to those who are responsible for it, a strict liability regime is more likely to achieve that end. ${ }^{46}$

The foregoing discussion exposes some of the ambiguities surrounding the PPP. The principle has evolved over time towards full internalisation of pollution costs, but who the polluter is and what kind of damage should be compensated remain contested. The international compensation regime for marine oil pollution examined below takes its own particular approach to these elements of the PPP.

41 Environmental Liability Directive (n 24).

42 Oil Pollution Act, 199033 USC § 2701ff.

43 UN Convention on the Law of the Sea (regime for deep sea-bed mining) (1982) pt X1 and Protocol on Environmental Protection to the Antarctic Treaty (1991).

44 The international regime imposes strict liability upon the shipowner, in the first instance.

45 Including the international oil pollution liability conventions as well as the Convention on Civil Liability for Damage Resulting from Activities Dangerous to the Environment, Council of Europe, European Treaty Series-No 150, Lugano.21.VI.1993 and the Environmental Liability Directive (n 24). 


\section{THE INTERNATIONAL LEGAL FRAMEWORK}

In examining the international regime, it is worth remembering that it was aimed at providing timely compensation for the victims of oil pollution, not at punishment or prevention, nor with a view to ensuring that the responsible parties were to pay the cost of pollution. Also, as noted previously, the PPP is not an accepted principle of international law and consequently lack of explicit reference to the principle in the international regime comes as no surprise. The International Maritime Organisation (IMO) adopted two separate instruments in $1969^{47}$ and $1971 .^{48}$ The 1969 Civil Liability Convention (CLC) places strict liability on tanker-owners, but liability is limited according to vessel size, unless the damage is the result of a personal act or omission of the shipowner with the intent to cause damage or recklessly and with knowledge that such damage would probably result. ${ }^{49}$ The 1971 supplementary scheme allows for additional compensation for the victims of oil pollution, which is financed by the oil industry. Thus, if the cost of damage exceeds the limits of liability of the tanker-owner, claims can be made against the fund. Liability is also limited under the 1971 Convention $^{50}$ and the channelling of liability onto the shipowner can only be circumvented under the same conditions. ${ }^{51}$

The original treaties were amended in 1992 and limits of liability were substantially increased for both tanker-owners and oil interests. ${ }^{52}$ In response to the demise of the vessel 'Erika' in 2000, the IMO adopted further amendments to the treaties, which once again raised the limits of liability and compensation. ${ }^{53}$ However, these were not yet in force at the time of the sinking of the 'Prestige' in $2002 .{ }^{54}$ The overall balance in terms of share of liability was, however, retained. The Civil Liability Convention, Fund Convention and the Supplementary Fund all provide compensation for 'pollution damage'. 55 This is further qualified by the International Oil Pollution Compensation (IOPC) Fund Claims Manual, which makes clear that loss of property and economic loss are covered, but limits reinstatement to 'reasonable measures' (a term that is not defined). ${ }^{56}$ The IOPC fund have made clear that

UNTC 14097 International Convention on Civil Liability for Oil Pollution Damage, Brussels, 29/11/ 1969, UNTS vol 973 p 3, entered into force 19 June 1975 (the Civil Liability Convention).

48 UNTC 17146 International Convention on the Establishment of an International Fund for Compensation for Oil Pollution Damage, Brussels, 19/12/1971, UNTS vol 1110 p 57, entered into force 16 October 1978 (The Fund Convention).

49 The Civil Liability Convention (n 47) art V(1).

50 The Fund Convention (n 48) art 4(4)(a).

51 The Civil Liability Convention (n 47) art III(4).

52 UNTC 14097 Protocol of 1992 to amend the International Convention on Civil Liability for Oil Pollution Damage, 1969, London 27/11/92, UNTS vol 1956, entered into force 30 May 1996 and UNTC 17146 Protocol of 1992 to amend the International Convention on the Establishment of an International Fund for Compensation of Oil Pollution Damage 1971, London 27/11/92, UNTS vol 1953, entered into force 30 May 1996.

53 Protocol of 2003 to the International Convention on the Establishment of an International Fund for Compensation for Oil Pollution Damage, 1992, London 16/5/03, entered into force 3 March 2005.

54 The amendments raised the total amount of compensation payable in a single incident to around 110 million euros.

55 The Civil Liability Convention (n 47) art I(6); The Fund Convention (n 48) art 1(2).

56 IOPC Fund, International Oil Pollution Compensation Funds Claims Manual, October 2016 edn, para 1.4 . 
'pollution damage' does not encompass pure environmental damage, ${ }^{57}$ leaving a situation whereby it is a more favourable result in terms of liability to have complete destruction of an environmental feature rather than damage that can be rectified.

\subsection{The Influence of Shipping and Oil Interests in the International Regime}

The features of the international regime examined above were shaped by powerful shipping and oil interests. After the demise of the 'Torrey Canyon' in 1967, the need for action to compensate for damage caused by oil pollution was clear, but at the same time industry players sought to protect their own interests in the global oil trade. The diplomatic conferences that preceded the drafting of the 1969 and 1971 Conventions were attended by representatives of both the shipping and oil industries and their contributions to the negotiations had a significant impact upon the form of the final instruments. ${ }^{58}$ In addition, to pre-empt any action by individual states, which might be detrimental to their interests, tanker owners entered into a voluntary agreement to reimburse the cost of clean-up incurred up to a maximum liability limit. ${ }^{59}$ This agreement was clearly also intended to influence negotiations on an intergovernmental instrument and, indeed, TOVALOP had many similar features to the subsequently adopted CLC. ${ }^{60}$ In fact, it fulfilled the purpose of compensation for oil pollution damage until the CLC came into force in $1975 .{ }^{61}$ Similarly, the Contract Regarding an Interim Settlement of Tanker Liability for Oil Pollution (CRISTAL) was intended to influence negotiations at the 1971 diplomatic conference. ${ }^{62}$ CRISTAL was a supplementary fund financed by the oil companies for compensation over and above the liability limits set in TOVALOP. The similarity with the subsequent Fund Convention ${ }^{63}$ is clear and this supplementary fund provided an additional source of compensation until it came into force in 1978.

Shipping and oil interests continue to play a significant role in the international regime and to influence its direction, particularly with regards to the nature of liability for pollution damage. International non-governmental organisations (NGO) (including business associations) have consultative or observer status at fund meetings and participate in inter-governmental discussions. NGOs do not have a right to vote in these assemblies but voting rarely takes place and their influence is significant in decisions on policy and law. ${ }^{64}$ It is also the case that many decisions on shipping regulation are made according to global share of shipping owned by states. The six countries that register half of the world's shipping volume include Panama, Liberia,

IOPC Fund Assembly Resolution No 3 of 10 October 1980 (FUND/A/ES. 1/13, para 11.a and Annex I) formalised in the 1984 Protocol to the Civil Liability Convention, art 2.3.

58 Michael M'Gonigle and Mark Zacher, Pollution, Politics and International Law (University of California Press 1979); Alan Tan, Vessel-Source Marine Pollution (CUP 2006); James Harrison, 'Regime Pluralism and the Global Regulation of Oil Pollution Liability and Compensation' (2009) 5 Int JL Context 379, 385.

59 Tanker Owners Voluntary Agreement concerning Liability for Oil Pollution (TOVALOP).

60 The Civil Liability Convention (n 47).

61 Harrison (n 58).

62 IMO Conference on the Establishment of an International Compensation Fund for Oil Pollution Damage, 29 November-18 December 1971 (LEG/CONF.2); ibid.

63 The Fund Convention (n 48).

64 Harrison (n 58) 384. 
Malta and the Bahamas ${ }^{65}$; the main 'flag of convenience' providers who will clearly exert a disproportional influence upon such decisions. Private interests have also continued to operate out-with the international regime where they have been unable to influence its amendment. ${ }^{66}$ STOPIA and TOPIA have the effect of significantly raising the liability of tanker owners and, therefore, reducing the burden upon the oil industry. ${ }^{67}$ Both are contractual agreements enforceable under English law, but, judging by past developments, they are likely to have a significant impact upon the inter-governmental regime for oil pollution liability and compensation.

Given the significant influence of oil and shipping interests explored above, it is perhaps no surprise that the international regimes set clear limits on the sums of compensation available and provide, in the first instance, for sole responsibility with the ship owner under the CLC. The big shipping organisations are then protected by the dispersal of liability through 'one ship companies'. Despite consistent calls for limits on compensation to be abolished, ${ }^{68}$ although increased in 2003, ${ }^{69}$ they have not been significantly raised and remain intact. The powerful international oil and shipping interests accepted potential liability on their own terms to be able to continue to ship oil around the globe and their continued influence over the shape of the international regime has determined the nature of that liability and the way in which it reflects the PPP.

\subsection{The International Regime and the PPP}

In examining the role of the PPP in the international regime for oil pollution compensation, it is important to be cognisant of the context and timing of the regime's inception. Its development followed swiftly on the heels of the 'Torrey Canyon' disaster in 1967 long before the first articulation of the PPP from the OECD. This was a time when environmental policy and law were in their infancy and many of the features of the regime were innovative and ahead of their time. ${ }^{70}$ The dangers involved in transporting persistent heavy fuel oils around the globe by sea and the devastating long-term environmental consequences of oil spillage were, however, clearly issues to contend with and the international regime set out to do this by introducing a swift mechanism to compensate for damage caused by oil pollution. The task was not an insubstantial one. International agreement across nations with varying degrees of interest in shipping, oil and the marine environmental was needed and this, alongside accommodating the powerful shipping and oil interests discussed above.

The channelling of liability on the shipowner, in the first instance, ${ }^{71}$ under the international regime clearly does not meet the demands of the PPP. In all but the

65 Friends of the Earth, 'Prestige Oil Spill-Who Foots the Bill?' (November 2002) 1. The others being Cyprus and China.

66 Small Tanker Oil Pollution Indemnification Agreement (STOPIA) 2006, art IV(c) (1); Tanker Oil Pollution Indemnification Agreement (TOPIA) 2006, art XVI(c); Harrison (n 58) 387.

67 STOPIA, art IV(c) (1); TOPIA, art XVI(c).

68 For example, in the Proposal for a Directive on Ship-source Pollution and on the Introduction of Sanctions, Including Criminal Sanctions for Pollution Offences (2003) COM(2003)92 final, Explanatory Memorandum, para 2.2.

69 The Fund Convention (n 48).

70 For example, provision for preventative and compensatory measures.

71 The Civil Liability Convention (n 47) art III(1). 
most serious marine oil pollution incidents, the shipowner will be liable for the full extent of the damage, regardless of the contribution of other parties to the pollution. The Fund Convention does provide for an element of shared responsibility ${ }^{72}$ and, in terms of application of the PPP, this means that, at least in the more serious cases of oil pollution damage, the owners of the ship and the owners of the cargo are both treated as polluters and share the cost of pollution damage. ${ }^{73}$ However, the contribution of oil receivers to the fund and to any subsequent pay-out is irrespective of direct responsibility for the pollution ${ }^{74}$ and this kind of insurance-like arrangement does not accord with the PPP. Furthermore, there is no forensic analysis of responsibility and the allocation of liability and the activation of the secondary layer of compensation are based purely on pre-prescribed formulae. ${ }^{75}$ Costs of damage falling outside the Conventions were traditionally borne by the victims of the pollution, which appears to run counter to the PPP. However, this does align with the 'user pays principle' if authorities contribute to the cost of serious pollution incidents and pass part of the burden on to the ultimate beneficiaries of oil use-the public. This kind of distribution under the PPP is not without difficulties, not least in distinguishing between categories of oil users within the public. ${ }^{76}$ Nonetheless, some sort of overarching responsibility on the part of national authorities on behalf of those who all use or benefit from oil in some form or other is not unthinkable.

The international regime adopts a strict liability approach, which accords with the tradition in maritime law ${ }^{77}$ and is the preferred model of liability under the PPP. The use of strict liability ensures that those engaged in hazardous activities bear responsibility for any pollution that results regardless of whether fault can be shown and can thus ensure optimum internalisation of costs. However, the international regime has been subject to criticism for its failure to allow compensation for pure environmental damage along with the limits of 'reasonable' re-instatement. ${ }^{78}$ There is no definition in the $\mathrm{CLC}^{79}$ or the Fund Convention ${ }^{80}$ of 'reasonable' in this context and this limitation is worrying in terms of the application of the PPP. The term 'reasonable' brings with it clear connotations of economic considerations and limiting compensation in this way runs counter to the goal of optimising cost internalisation. The IOPC Fund Assembly has been consistent in its position on restricting compensation to cover the costs of measures 'actually undertaken' or to be undertaken and in its resistance to any valuation of environmental loss. ${ }^{81}$ The lack of compensation

Harrison (n 58) 380.

Birnie, Boyle and Redgwell (n 6) 436.

The Fund Convention ( $\mathrm{n} 48$ ).

The Civil Liability Convention (n 47); The Fund Convention (n 48).

Bleeker (n 5) 298.

Eduard Somers and Gwendoline Gonsaeles, 'The Consequences of the Sinking of the M/S Erika in European Waters: Towards a Total Loss for International Shipping Law?' (2010) 41 J Mari L Comm 57, 64.

8 See eg The European Commission, Erika I package, COM (2000) 142 final, 34-35; Michael Mason, 'Transnational Compensation for Oil Pollution Damage: Examining Changing Spatialities of Environmental Liability' (2002) < http://eprints.lse.ac.uk/570/> accessed 3 July 2017.

The Civil Liability Convention (n 47).

The Fund Convention ( $\mathrm{n} 48$ ).

See n 57. 
for a damaged feature of the marine environment that does not hold the capacity for restoration certainly leaves a stark hole in any assessment of the international regime for compliance with the PPP. However, whilst a few states have for some time embraced compensation for environmental damage per se along with valuation models, ${ }^{82}$ it is not until quite recently that this practice has been adopted under the PPP, in the EU, for example. ${ }^{83}$ It is also common for the degree of restoration in other areas of environmental law, where the PPP is applied to be limited by economic factors and/or the principle of proportionality ${ }^{84}$ to what is 'reasonable'.

As noted at the beginning of this section, the international regime was not designed with the PPP in mind and the principle itself, although it has been referred to as a general principle of international law, ${ }^{85}$ probably does not have customary law status. Furthermore, where the PPP appears in international instruments, it is couched in the softest terms and the need to balance the principle with financial and trade interests is explicitly recognised. ${ }^{86}$ That said, the international regime clearly does incorporate features of the extended PPP. It adopts a strict liability approach and elements of the 'user pays principle' can be recognised in the arrangements for sharing responsibility and passing some of this onto the general public. Importantly where the international regime interacts with national and regional law it opens the doors to cross-fertilisation and development of the PPP and this is well illustrated in the 'Erika' and 'Prestige' pollution incidents discussed below.

\section{THE TALES OF THE 'ERIKA' AND THE 'PRESTIGE'}

Certain significant maritime disasters have shaped the direction of the law on liability for accidental oil pollution. The 'Torrey Canyon' disaster mentioned above was followed by the sinking of the 'Exxon Valdez' off the coast of Alaska in 1989. The release of huge quantities of oil from the vessel with disastrous consequences to an environmentally sensitive area led the USA to take a separate direction in liability for accidental oil pollution damage. ${ }^{87}$ Other notable incidents followed, such as the demise of the 'Braer' off the coast of Scotland in $1993 .{ }^{88}$ However, until the 'Erika' and 'Prestige' disasters, the international regime had sufficient funds to compensate for the pollution damage caused within the ambit of the Conventions. The consequential damage suffered following the 'Erika' and 'Prestige' disasters was to prove a challenge to the international regime in terms of cost as well as in determining liability.

83 The Environmental Liability Directive (n 24).

84 For example, in Case C-239/97, The Queen v Secretary of State for the Environment and Minister of Agriculture Fisheries and Food ex parte H.A. Standley and Others and D.G.D. Metson and Others [1999] ECR I-02603.

85 Sands and Peel (n 28).

86 For example, the formulation in Principle 16 of Agenda 21 in the Rio Convention (n 25).

87 US Oil Pollution Act (n 42).

88 The oil tanker 'Braer' ran aground and later broke up in January 1993 during the worst extratropical cyclone recorded for the Northern Atlantic Ocean. 


\subsection{The 'Erika'}

The 'Erika' was a single-hulled vessel of nearly 25 years of age and was practically the only asset of the owning company. Prior to the voyage in question, she had changed hands and name seven times and had previously suffered damage. ${ }^{89}$ Her ownership is a classic case of complexity and the use of shell-companies and would lead to subsequent problems in determining liability. Total Transport Company (France) had chartered the 'Erika' to transport heavy fuel oil from Dunkerque in France to Milazzo in Italy. She was carrying 31,000 tonnes of one of the most polluting hydrocarbons with one of the lowest economic values when she left Dunkerque on 8 December 1999. After encountering heavy swells and developing a severe list, the tanker ultimately broke in two in the Bay of Biscay some 45 nautical miles off the coast of Brittany during the night of 13th December. ${ }^{90} 19,800$ tonnes of the 'Erika's' cargo of heavy fuel oil was spilled, polluting $400 \mathrm{~km}$ of the French coastline in the worst ever environmental disaster in France. ${ }^{91}$ As a result of the oil pollution, and despite a massive clean-up exercise, thousands of seabirds wintering on the French coast were killed.

\subsection{The 'Erika' Cases}

\subsubsection{Case C-188/07, Commune de Mesquer v Total France SA}

Following the 'Erika' disaster, the Commune de Mesquer, an area badly affected by the subsequent effects of oil pollution, brought proceedings against Total France SA and Total International Ltd (Total) for the reimbursement of its clean-up costs over and above the compensation already received from the IOPC Fund. Due to the channelling of liability upon the shipowner, in the first instance, and limits on liability under the international regime, Total's liability for compensation was limited. The action in the French courts against Total was brought under EU waste law, which did not provide for any limits to liability. As a previous holder of the 'waste', Total could be strictly liable for the cost of all of the damage. ${ }^{92}$ The action to recover the extra clean-up costs was unsuccessful at first instance ${ }^{93}$ and, on appeal, the first instance judgment was confirmed. ${ }^{94}$ The Municipality then appealed on a point of law to the Cour de Cassation on the basis that this resulted in a problem with the interpretation of Directive $75 / 442 / \mathrm{EEC}$ on waste. ${ }^{95}$ The Cour de Cassation referred three questions by way of preliminary reference to the Court of Justice of the EU.

89 Vincent Rebeyrol, 'The Erika Case: An Incitement to Rewrite the CLC' (2013) 22 EEELR 33, 34.

90 IOPC Fund, 'Report on the Activities of the International Oil Pollution Compensation Funds in 2007' (2007) 77-90.

91 Vincent Foley and Christopher Nolan, 'The Erika Judgment-Environmental Liability and Places of Refuge: A Sea Change in Civil and Criminal Responsibility that the Maritime Community Must Heed' (2008) 33 Tulane Marit LJ 41, 44.

92 By then, codified in Directive 2006/12/EC of the European Parliament and of the Council of 5 April 2006 on Waste [2006] OJ L114/9, art 15.

93 Tribunal de Commerce de Saint-Nazaire no A0-408, Commune de Mesquer $v$ Total Raffinage Distribution and Total International Ltd, 16 December 2000, JurisData no 2000-2047641 3 Droit Maritime Francais 259-81 (2001).

94 Cour d'Appel de Rennes (F) no 00/08026, Commune de Mesquer v Total France SA and Total International Ltd, 13 February 2002, JurisData no 2002-204764; Environnement 51ff (2002). 
Following the principles established in the Van der Walle case, ${ }^{96}$ the Court of Justice found that once the hydrocarbons, which had been accidentally spilled, were mixed with sediment they constituted waste for the purpose of the Directive. ${ }^{97}$ The Court of Justice also addressed the question of the conflict between EU and international regimes. The EU is not a party to the inter-governmental regimes, whereas most of its Member States, including France, are parties to the Conventions. Whilst acknowledging the right of Member States to adopt the limitations on liability imposed under international law, the court saw no problem with a secondary layer of EU liability. ${ }^{98}$ Thus, it found no conflict between the two sets of obligations at EU and international level and held that national law was to ensure that any further costs incurred outside the limits of international law were 'borne by the producer of the product from which the waste thus spread came'. ${ }^{99}$ Although de Sadeleer suggests that the Court's reasoning is 'convincing and sound', ${ }^{100}$ the international regime clearly and unequivocally dictates that no additional claims can be made outside its remit $^{101}$ and the European Commission had previously acceded that 'this means that it would be very difficult for the Community to impose additional individual liabilities on ship owners or any of the protected parties without being in conflict with the international conventions'. ${ }^{102}$ The arguments surrounding the EU's subsequent explicit authorisation for Member States to accede to the 2003 Protocol to the international regime were dismissed by Advocate General Kokott as this post-dated the accident. ${ }^{103}$ Yet, this instruction to Member States does point to a clear steer from the EU, which is underlined by the fact that accidental oil pollution incidents covered by the international regime were explicitly excluded from the Environmental Liability Directive passed just 2 years after the 'Erika' disaster. ${ }^{104}$

The Court of Justice answered in the affirmative to the question of whether Total could be liable for the costs of disposal as a prior holder and contributor to the causal chain that created the waste, again applying principles derived from Van der Walle. ${ }^{105}$ The Court used its interpretive powers to effectively extend the reach of the PPP by concluding that the seller of the oil and the charterer of the vessel had 'produced' the waste by contributing to the risk that the pollution caused by the shipwreck would occur. ${ }^{106}$ They had so done by failing to take measures to prevent the accident. Thus, the Court further concluded that the seller and the vessel's charterer were both 'previous holders' of the waste for the purposes of Article 15 of the Waste Framework Directive. ${ }^{107}$ This was despite the opinion of Advocate General Kokott,

Case C-1/03 Van der Walle v Region de Bruxelles-Capitale [2004] ECR I-7613.

Case C-188/07, Commune de Mesquer v Total France SA [2008] ECRI 4501 [2008] 3 CMLR 16 [63]. ibid [81], [82].

ibid [77].

Nicolas de Sadeleer, 'Liability for Oil Pollution Damage versus Liability for Waste Management: The Polluter Pays Principle at the Rescue of the Victims' (2009) 21 JEL 299, 306.

The Civil Liability Convention (n 47) art III, para 4.

European Commission 'Erika II Package' COM (2000) 802 final, 59.

Case C-188/07 (n 97) [85].

The Environmental Liability Directive (n 24).

Case C-188/07 (n 97) [77], [78].

ibid [82].

ibid [78]. 
who argued that the passing on of a great part of environmental liability to the public under the international regimes accorded with the PPP. ${ }^{108}$

\subsubsection{Cour de Cassation Judgment of 25 September 2012}

Whereas the Commune de Mesquer case above concerned the liability of Total, the Cour de Cassation judgment followed an appeal against a decision of the Court of Appeal on criminal liability in Paris in 2010. ${ }^{109}$ In the Court of Appeal, the shipowner, the management company, the classification society and Total SA were all found criminally liable for the offence of causing pollution. The Court also considered civil liability and determined that all parties, apart from Total SA, were also liable in civil law. In the Cour de Cassation, one of Total's arguments was that the criminal conviction ran counter to the international conventions, which channel liability on ship owners rather than charterers.

The Cour de Cassation upheld the decision that Mr. Savarese (the President of the owning company, Tevere Shipping) was the agent of the owner and thus fell within the channelling provisions of Article III(4) of the CLC. ${ }^{110}$ However, the court determined that his liability could not be excluded in the light of his recklessness. Mr. Savarese had consented to a request from Mr Pollara that work carried out by a shipyard in Montenegro in 1998 on the 'Erika' was performed to a minimum and insufficient standard at a significantly reduced cost. He had also chartered the 'Erika' when he knew that she was in a dilapidated condition due to inadequate maintenance and in risk of accident and sinking. The Court concluded that Mr Pollara was the agent of the company performing services for the ship (Panship Management) and, therefore, fell within the channelling provisions of Article III(4), but was likewise not excluded from liability because of his reckless actions. As well as deciding to make the minimum repairs, he was the first person informed of the ship's difficulties and the spillage of oil and yet had not informed the coastal authorities.

The Court, also determined that the Court of Appeal had erred in concluding that a classification society could not benefit from the channelling provisions. ${ }^{111}$ Article III(4) excludes 'any other person who, without being a member of the crew, performs services for the ship'. The Court of Appeal had determined that classification societies, although paid by the shipowner, were exercising public powers in the interest of the public and, as such, did not fall within the ambit of the exclusion. The Cour de Cassation rejected this reading of the Convention, but also found the classification society (RINA) to have acted recklessly. ${ }^{12}$ This was based upon the ship having been certified to sail even though a summary inspection had shown an advanced state of corrosion following recent repair.

Reversing the decision of the Court of Appeal, the Cour de Cassation imposed civil liability under French law on Total SA. Again, as the damage also resulted from the recklessness of the charterer, the court determined neither could Total rely upon the

108 ibid [142].

109 L'arret no 1, Pole 4, Chambre 11 E du 30 Mar 2010 (08-02278) du Cour d'Appel.

110 L'arret no 3439 du 25 Sep 2012 (10-82938) de La Chambre Criminale [214-17].

111 ibid [423].

112 ibid. 
limitations imposed by the international regime. The Court of Appeal had concluded that Total, as the 'time charterer' of the ship, clearly fell within the list of beneficiaries of the exoneration provided under Article III.4. They found that, although negligent in not having adhered to the oil company's in-house vetting procedure, it was unlikely that Total were aware that the ship had deteriorated sufficiently to be at risk of sinking and impossible to charter. ${ }^{113}$ The Cour de Cassation, however, concluded that Total was liable as it had acted recklessly within the meaning of Article III(4). There is little elaboration upon this conclusion, the court simply asserting that Total's representative, in not insisting upon a new vetting of the 'Erika', was 'necessarily aware of the damage by pollution that would probably follow. ${ }^{114}$

The Court of Appeal had broken new ground in terms of the PPP by recognising pure environmental damage as a head of compensation ${ }^{115}$ and the Cour de Cassation reinforced this recognition and defined such damage as 'direct or indirect damage inflicted on the environment and resulting from the infringement'. ${ }^{116}$ Thus, damages were awarded in French law under three heads: (1) economic losses (2) moral prejudice and (3) environmental harm.

\subsection{The 'Prestige'}

Just 3 years after the 'Erika' went down off the coast of Brittany, the 'Prestige' sank off the Galician coast, causing severe environmental damage to coastal areas of Spain, France and Portugal. The 'Prestige' was a 26 year-old single hulled oil tanker, constructed in Japan, registered in the Bahamas and flying a Bahamian flag. ${ }^{117}$ As with the 'Erika' the ownership of the 'Prestige' was complex, involving a network of front companies and the identity of the true owner remains unknown. ${ }^{118}$ The vessel was carrying around 77,000 tonnes of heavy fuel oil when, on 13 November 2002, she encountered a storm off the Galician coast in North West Spain. She developed a severe list and drifted towards the coast. One of the vessel's 12 oil tanks burst and the captain called upon Spain for help. Rather than allowing the tanker into harbour, the local authority instructed the captain to steer away from the coast. The 'Prestige' finally broke in half on the morning of 19th November and sank later that day around $250 \mathrm{~km}$ from the Spanish coast. More of the vessel's cargo of heavy fuel oil entered the ocean and she continued to leak oil at the rate of approximately 125 tonnes per day. In total around 63,000 tonnes of her oil cargo were spilled. The spill polluted $2980 \mathrm{~km}$ of coastline and over 1000 beaches of Spain, France and Portugal. It was the single largest environmental disaster in the history of both Spain and Portugal with an estimated cost of over 4 billion Euros. ${ }^{119}$ The effects were

113 See n 109.

114 ibid.

115 Nathalie Herve-fournereau (tr), 'National Report FRANCE' (Avocetta Meeting, Helsinki, 2013).

116 See n 109.

117 Juste-Ruiz (n 33).

118 Mark Schapiro, 'Spain, The Lawless Sea' (Frontline World, January 2004) <http://www.pbs.org/frontli neworld/stories/spain/thestory.html> accessed 23 June 2018.

119 Marianne Barriaux, 'Spain Court Finds Captain, British Insurer Liable for Prestige Oil Spill' (Coastal Care, 26 January 2016) <http://coastalcare.org/2016/01/spain-court-finds-captain-british-insurer-li able-for-prestige-oil-spill/ $>$ accessed 23 June 2018. 
particularly notable in the territory of Galicia in Spain, where an important ecological region sustained significant damage and offshore fishing was suspended for 6 months. $^{120}$

\subsection{The 'Prestige' Cases}

\subsubsection{New York Court of Appeal Judgment, August 2012}

The legal situation with regards to the classification society in the 'Prestige' incident was different to the 'Erika' because the 'Prestige' was classed by a US society, the American Bureau of Shipping (ABS). The USA is not a party to any of the international conventions, so the protection under such arrangements did not apply. Spain appealed against a decision that ABS were exempt from liability ${ }^{121}$ on the basis that they should not fall outside of the group of potentially liable parties because their conduct was reckless. The District Court did not provide an answer on whether US classification societies can be liable in tort in the US courts but decided the case purely on the question of 'recklessness'. They determined that there had been no recklessness on the part of $\mathrm{ABS}$ and, therefore the position with regards to the liability of non-party state classification societies remains in doubt. It is interesting, particularly in comparison to the Cour de Cassation case explored above, that the court found no recklessness given a long list of errors on the part of ABS alleged by the claimant.

\subsubsection{Decision of Spain's Supreme Court, Madrid, 14/1/16}

In November 2013, the Galician Region High Court delivered its judgment on criminal proceedings instituted in 2002 against four parties; the Master, Chief Officer and Chief Engineer of the 'Prestige' as well as Mr Lopez-Sors, the Spanish official who had ordered the vessel to sail away from the coast. Civil claims were added to the proceedings in 2010 against the owner of the 'Prestige' (Mare Shipping Inc.) and their insurers (London Steamship Owners Mutual Insurance Association Limited). The court found all parties not guilty of the criminal charges ${ }^{122}$ and found the insurer's civil liability to be limited to their responsibility under the CLC. ${ }^{123}$ The decision was appealed to the Spanish Supreme Court and two judgments of the Spanish Supreme Court dated 14 January 2016 partly overturned the judgment of the Provincial Court of La Coruna.

Faced with no criminal offence, the Galician Court had been unable to reach a decision on compensation under civil law. The Supreme Court, however, found that the master of the vessel was negligent and that his negligence amounted to wilful misconduct under Article V.3 of the CLC and thus civil liability was unlimited. ${ }^{124}$ This decision was based primarily on the fact that the master was aware of deficiencies and faults with the 'Prestige' before she sailed along with the possibility of bad case-study/prestige-spainfrance-2002/> accessed 23 June 2018.

121 Reino de Espana v American Bureau of Shipping, 10-3518 cv, 29 August 2012.

122 Captain Apostolos Mangouras was found guilty on a lesser charge of disobedience.

$12322,777,986$ euros.

124 The Civil Liability Convention (n 47) art III(4). 
weather. ${ }^{125}$ The court found that these factors together with the taking on of further cargo had hindered the seaworthiness and manoeuvring ability of the vessel following the initial damage to its hull. The court concluded that the master's seamanship was dangerous, saying that he created a serious risk, particularly with regards to the highly-polluting nature of the substance he was transporting. ${ }^{126}$

In addition, the Supreme Court found the owner and classification society civilly liable. The owner was held to be vicariously liable having also acted with wilful misconduct such that there was no limit to liability under the CLC. The court concluded that the registered owner must have known of the condition of the vessel. The 'Prestige' had been vetoed by other oil companies ${ }^{127}$ and was forbidden to sail in several countries. A witness attested to the fact that the vessel was intended to be scrapped at the port of origin, but a decision had been made to employ her on one final voyage. The insurer (The London Club) had already attained a negative declaratory judgment from the UK Commercial Court, effectively limiting its liability to the insured amount of 22,777,986 Euros under Article 7 of the CLC. ${ }^{128}$ Furthermore, the Civil Bench of the Spanish Supreme Court had held in a judgment of 3 July 2003 that Spanish courts did not have jurisdiction to entertain a direct claim against a P\&I Club as such claims are subject to arbitration. ${ }^{129}$ However, the Supreme Court noted that the Club had chosen not to defend itself even though summoned and that they had gone beyond the 'pay to be paid' rule when they deposited the amount insured with the Court. In any event, they were directly responsible in Spanish law because the civil liability flowed from a criminal offence. There was, in fact, additional insurance over and above the amount deposited and the Spanish Supreme Court held that the London insurer was responsible for the total amount of liability insured. ${ }^{130}$

On the matter of recovering for pure environmental damage, the civil liability established in the judgment covered restoration and reparation of damage. Damages were recovered under three heads, material damages, moral damages and environmental damage, ${ }^{131}$ similarly to the decision on categorisation of damages in the Cour de Cassation. Although there was no explicit judicial recognition of environmental damage per se by the Supreme Court, they determined that the compensation payable by the fund could not exclude damages that did not exactly match those eligible for compensation under the Fund Convention and, furthermore that the IOPC

(n 120) eg, the automatic piloting system was no longer functional.

Sentencia No 865/2015.

ITOPF (n 120) Reposol (Spain) and BP.

The London Steam-Ship Owners' Mutual Insurance Association Ltd v The Kingdom of Spain and the French State [2013] EWHC 3188 (Comm). A subsequent appeal lodged by Spain and France against the Judge's order and heard by the Court of Appeal in January 2015 was dismissed in The London Steamship Owners' Mutual Insurance Association Ltd v The Kingdom of Spain and The French State (The 'Prestige') [2015] EWCA Civ 333.

Julio Lopez Quiroga and Hannah de Bustos, 'The Spanish Supreme Court Judgement on the "Prestige" Casualty' (CorporateLiveWire, 2016) <http://www.corporatelivewire.com/top-story.html?id=the-span ish-supreme-court-judgment-on-the-prestige-casualty $>$ accessed 23 June 2018.

ibid. 1 billion USD.

Albors, Galiano and Portales, 'Prestige: Judgment of the Spanish Supreme Court' (1 February 2016) $<$ http://www.alborsgaliano.com/2016/02/01/prestige-judgment-of-the-spanish-supreme-court/?lang=en> accessed 23 June 2018. 
Fund Claim Manual was to be used for guidance purposes only. Thus, it seems that the door is also opened for compensation for pure environmental damage in Spain.

\section{APPLICATION OF THE PPP IN THE COURTS}

Following the summary above, this section turns to consider how the PPP was applied by the courts in these cases. The Commune de Mesquer case was the latest of a line of cases $^{132}$ before the Court of Justice where the court has developed the PPP in a doctrinal way by using it as an interpretive aid. ${ }^{133}$ Prior to this case, the position established by the court was that the PPP only imposes the burden of remedying pollution upon those who have contributed to the polluting incident. ${ }^{134}$ However, there is clearly a wide margin of discretion that rests with Member States on application of the principle in accordance with local conditions. ${ }^{135}$ The Commune de Mesquer case extends the principle to embrace those contributing to the risk that pollution is caused. ${ }^{136}$ Applying this, the court answered in the affirmative on the question of whether Total could be the producer and or holder of waste and held that imposing liability on Total accorded with the PPP. However, it is interesting to note the opinion of Advocate General Kokott in the case. She was of the view that passing on the additional clean-up costs over and above the limits of the international regime to the public accorded with the PPP. ${ }^{137}$ This would have been a way to contain EU jurisprudence within the bounds of the international regime by adhering to the limits in the international conventions. At the same time, it would have aligned the outcome with the 'user pays principle' by shifting part of the burden to the general public. There has been some criticism of the approach taken by the Court of Justice in this case, not least from those who see a clear distinction between the tradition of maritime law and the terrestrial law of the EU. ${ }^{138}$ However, putting aside issues around defining waste and the blurring of the distinctions between waste and contaminated land as well as between waste and marine pollution, there are interesting consequences for the development of the PPP, which flow from this decision. The much broader application of the principle by the Court of Justice is no surprise given the more entrenched position it holds in EU law. However, bringing oil companies who run the risk of oil pollution incidents into the frame of liability in this way could result in double application of the principle. The fund and the supplementary fund of the international regime are financed, in part, by oil companies, including Total. In the case of the 'Erika', the fund had been exhausted to its limit and it can be argued, therefore, that Total had already made some of its contribution under the PPP.

Whereas the decision of the Court of Justice involved the extension of liability through a supplementary layer of EU law, the decisions of the Court of Appeal and the Cour de Cassation in France on the civil liability of key actors in the demise of Raffinerie Mediterranee (ERG) v Ministero dello Sviluppo Economico [2010] ECR I-01919. 
the vessel 'Erika' required the application of the international regime in the national courts. The exoneration provisions of Art III(4) CLC have traditionally been advantageous to those other than the shipowner who are involved in a polluting incident. The very high threshold of fault required for other players to be caught in the liability net has previously protected all but the shipowner and led to effective channelling of liability. Thus, regardless of who is responsible for the pollution, the shipowner pays up to the limit as determined by the CLC. With mandatory insurance, this means that the first tranche of responsibility is met by insurers. However, faced with interpreting the level of recklessness required to remove other actors from their protected position under the international regime, the French courts found multiple contributors to the 'Erika' disaster liable, including, in the Cour de Cassation, the charterer and Total SA. No longer, it seems, is it such an advantage to be identified as one of the excluded parties under Art III(4). In terms of the application of the PPP, this clearly expands the remit of the international regime. Whereas, previously the shipowner was strictly liable irrespective of role in the polluting incident, there is now the opportunity to bring other players with direct responsibility for pollution into the liability pool: Albeit, the level of culpability involved remains high.

Significant in the findings of the French courts is their approach to environmental damage under the PPP. As noted, the administrators of the IOPC Funds have been consistently clear that compensation under the international regime is not available for environmental damage per se. Their position is that such damage is not quantifiable in financial terms. ${ }^{139}$ The recognition of pure environmental damage by both the Court of Appeal and the Cour de Cassation in applying the international regime is, thus, a controversial move that opens the possibility of an expanded definition of pollution damage in the national courts. Interestingly, the Court of Appeal did not find liability for pure environmental damage to be at odds with the 1992 CLC, saying that the provisions in Article I(6) excluding environmental compensation except in cases of reinstatement did not prevent compensation for pure environmental damage. ${ }^{140}$ Furthermore, in the light of the 'Erika' cases and commentary, ${ }^{141}$ in 2013, a working group in France proposed inclusion in the Civil Code of a new responsibility for pure environmental damage, which came into force in $2016 .{ }^{142}$ This, leaves France, as an individual party to the international conventions, in the position where, despite the observation of the Cour de Cassation, French law on compensation for environmental damage would appear to be at odds with international law.

Whilst French case law has opened the door for classification societies to pay for the cost of pollution, the New York Court of Appeal judgment of 2012 highlights some of the potential problems of extending the ambit of the PPP within the international regime. The decision leaves open the question as to whether classification societies (and presumably other operators) based in the USA can be subject to liability if the threshold for recklessness is met. This question also remains unanswered

141 Giles Martin and Laurent Neyret, Nomennclatre des prejudices environnementaux (LGDJ Collection Droit des affaires 2012); Corrine Lepage, Rapport Mieux reparer le dommage environnemental (Club des Juristes 2012). Title IV, Livre 111 of the Civil Code, arts 1386-19, 20 and 21. 
were operators to be based in other non-party states. It also raises the problem of national courts applying different standards of recklessness across jurisdictions. This leaves the position whereby, depending upon where the polluting company is registered and where judgment is made, the polluter may or may not pay.

The decision in the Galician High Court a little over 1 year after the Cour de Cassation ruling took a very different turn in terms of extending polluter liability beyond the vessel owner. ${ }^{143}$ However, it seems likely that this decision was influenced by political factors ${ }^{144}$ and in the Spanish Supreme Court in 2016, not only did the court find the requisite level of negligence with the master of the vessel, but they also found the vessel owner to be vicariously liable. Likewise, the court concluded that the classification society had acted in such a reckless way as to override their protection from liability. Thus, as in France, there is the possibility of broadened application of the PPP under the international regime. The Spanish Supreme Court, to a degree, also followed the Cour de Cassation in extending the ambit of the principle to cover environmental damage per se.

As previously noted, the shipowner's share of liability (if the requisite element of recklessness is lacking) is limited and subject to compulsory insurance. Faced with the possibility that the Galician court might find liability for the shipowner in excess of the limit, the London-based insurers of the vessel had sought to limit their liability by way of reliance on contractual provisions. Judgments of the Commercial Court and the Court of Appeal in the UK affirmed the insurers' limited liability. ${ }^{145}$ The sum insured was, in fact, much higher than the CLC limit and the Spanish Supreme Court held that the insurers were liable up to the total amount insured of 1 Billion USD. ${ }^{146}$ If the insurer's liability is limited, as confirmed by the UK Court of Appeal, then the shipowner may be exposed to uninsured losses, arguably ensuring fuller application of the PPP as payment comes directly from the pocket rather than by virtue of an insurance premium.

The decisions in the 'Erika' and 'Prestige' cases are significant in the development of the legal history of the PPP. Whilst precise definition of the principle remains elusive, certain trajectories of travel can be identified and the influence of legal developments in other jurisdictions is also apparent. The Court of Justice in the Commune de Mesquer case was not prepared to accept the restrictions on the PPP imposed by the international regime. Thus, rather than liability falling upon a single polluter, as favoured by the OECD Recommendation of 1975, the net was cast wider to capture another contributor. This approach to the PPP had already been accepted by the Court of Justice, but here they extended it to include those who contribute to the risk of an incident. The channelling of liability adopted by the international regime can indirectly lead to the public paying the price of pollution and thus bring the 'user 
pays principle' into play and this was argued although not accepted in the case, highlighting the potential for cross-fertilisation in the development of the PPP.

Similarly, the courts in France and Spain rejected the channelling of liability upon a single polluter, but in this case by interpreting the level of recklessness required by the international regime in such a way as to prevent the exclusion of other parties. There is no direct reference to the jurisprudence of the Court of Justice, but both countries are, of course, EU Member States. The national courts were also prepared to stray into the territory of compensation for pure environmental damage. Arguably, this reflects the true essence of the PPP by internalising all environmental costs. This divergence from the position of the international regime may well open opportunities for there to be re-consideration of the inclusion of this kind of damage within its ambit. Compensation for environmental damage per se certainly reflects the approach taken in the USA ${ }^{147}$ and, more recently, adopted by the EU and France. It is possible to identify a trajectory of travel in the history of the PPP from these cases and the Commune de Mesquer case towards broader conceptualisation of the 'polluter' along with a wider framing of environmental damage. This accords with the notion that all those responsible for pollution (directly or indirectly) should pay to fully internalise environmental costs.

\section{THE INTERNATIONAL REGIME IN JEOPARDY}

The decisions discussed above certainly strike a blow against the protected position of shipping and oil companies. There is now a potential antidote to the single company (often insolvent) ship owner bearing all initial responsibility and the ship charterer and the seller can also face strict and unlimited liability. However, these developments in the application of the PPP directly threaten the compromise position that exists under the international regime, whereby strict liability is accepted only on the terms of limiting the exposure of powerful interests to liability. Furthermore, the position taken by the Court of Justice with regards to competing international obligations for Member States places them in the difficult position of either dishonouring their international obligations or breaching EU law ${ }^{148}$ and thus potentially jeopardises the international regime.

The entrenched position of the PPP in European law, vis a vis international law may to some degree explain the approach of the Court of Justice and that of the courts in France and Spain. However, it is important to consider this in the broader context of EU maritime policy. The EU came relatively late to the development of an overarching policy for the marine environment. ${ }^{149}$ However, faced with the devastating consequences to Member States from oil pollution after the 'Erika' disaster,

147 US Oil Pollution Act (n 42).

148 Christina Eckes, Case C-188/07, Commune de Mesquer v Total France and Total International Ltd, Judgment of the Court (Grand Chamber) of 24 June 2008 [2008] ECR I-4501; Case C-301/08, Irene Bogiatzi v Deutscher Luftpool, Societe LUxair, European Communities, Luxembourg, Foyer Assurances SA, Judgment of the Court (Fourth Chamber) of 22 October 2009, not yet reported' (2010) 47 CMLR 899, 905.

149 Following Discussion Document European Commission 'Erika II Package' (2000) COM(2000)802 final, 59 'Towards a Future Maritime Policy for the Union; European Vision for the Oceans and Sea, the EU Maritime Green Paper'(2006) COM (2006) 275 final; European Commission 'Integrated European Marine Policy and Action Plan' (2007) COM (2007) 575. 
the European Commission was quick to propose legislative provisions. Three packages were put forward, the first only a matter of months after the 'Erika' sank. ${ }^{150}$ The proposals ranged from monitoring maritime traffic, port state control and phasing out single hull tankers amongst others. Controversially, in the second package, ${ }^{151}$ the Commission proposed an additional compensation fund to supplement that available under the International Regime.

In its Communication of 21 March 2000, the Commission expressed its view that the maximum level of compensation under the international regime was not sufficiently high to ensure that it met all potential claims resulting from an oil pollution incident. The Commission was also of the view that the system of channelling responsibility and limits based on a very high level of fault did not provide a disincentive for the carriage of oil in sub-standard vessels. ${ }^{152}$ As it happens, the European COPE Fund never actually came into being as the IMO created the Supplementary Fund in $2003,{ }^{153}$ which increased the maximum limit of liability to 750 million SDRs. ${ }^{154}$ However, despite consistent EU criticism of channelling limits and the strict liability regime, the international regime remains in essentially the same form today.

Whilst the Commission's criticism of the international regime clearly encompasses a desire to apply the PPP, particularly in its call for a raising of the maximum compensation limit to cover all claims, ${ }^{155}$ it must be remembered that there is resistance to change at a very fundamental level inherent in the international regime. The dominance of powerful oil and shipping interests is clearly a factor, which has previously been alluded to. Also, the organic mechanisms for change have traditionally flowed from industry initiatives in the first instance. ${ }^{156}$ Indeed, it has been suggested that the shipping industry and especially the key flag states, are not readily influenced by regional and more recent players in the field of shipping regulation. ${ }^{157}$ International shipping law is certainly grounded in conservatism and traditional patterns and a key feature of this is the close link in maritime law between strict liability and an accompanying limitation of exposure to liability. ${ }^{158}$ Indeed, Somers and Gonsaeles warn against the imposition of terrestrial environmental law to the international regime. ${ }^{159}$ They argue that legal solutions for land-based activities (such as waste) are not appropriate for the global marine environment and that only

151 See n 102. This was followed by the European Commission 'Third Maritime Safety Package' (2005) COM (2005) 585 final.

152 See n 78.

153 For commentary on the EU influence on the IMO, see Gwen Gonsaeles, 'The Impact of EC DecisionMaking on the International Regime for Oil Pollution Damage: The Supplementary Fund Example' in Frank Maes (ed), Marine Resource Damage Assessment, Liability and Compensation for Environmental Damage (Springer 2005) 85-131.

154 Special Drawing Rights (Around 110 million euros at the time).

155 See $n 78$.

156 See nn 59, 62, 66.

157 Somers and Gonsaeles (n 77) 65.

158 ibid 64, 65.

159 ibid 58. 
international measures grounded in traditional maritime law should be applied in this particular legal arena. 160

It is perhaps no surprise then that the International Chamber of Shipping (ICS) reacted in a strongly critical way to the judgment of the Spanish Supreme Court in the 'Prestige' case. The ICS specifically points out that limits on liability are the essential quid pro quo for shipowners agreeing a strict liability regime under the $\mathrm{CLC}^{161}$ and furthermore, that the agreed system of shared liability could be seriously undermined by the decision. ${ }^{162}$ This view echoes concerns in respect of the earlier Court of Justice ruling in the Commune de Mesquer case that the decision subverts the international system and may lead to its erosion and collapse in the future. ${ }^{163}$

Changes to the international regime have been considered and an intersessional Working Group was set up by the 1992 Fund Assembly in April 2000 to assess the adequacy of the international compensation system. The group reported in $2004{ }^{164}$ It was this group that was responsible for the drafting of a Protocol to establish the third tier of compensation. The group also considered environmental damage and revised the text of the Claims Manual to clarify the definition of 'pollution damage' and its exclusion of environmental damage per se. ${ }^{165}$ In its work, there was no substantive consideration given to the basic principles of limited liability or the channelling of liability, raised by the European Commission in 2000 and fundamental to the application of the PPP. ${ }^{166}$

Concerns were raised with the 1992 Fund Executive Committee following the judgment of the Spanish Supreme Court on consistency with the provisions of the 1992 Civil Liability and Fund Conventions. ${ }^{167}$ The Committee re-stated its view that the rule of law is paramount no matter how unpalatable the decisions of national courts might be. ${ }^{168}$ The concerns of the Spanish and industry observer delegations surrounded both the liability of the insurer and the master. On the first, the Committee was of the view that the proceedings in the UK had confirmed that there should be no liability over and above the CLC limit. ${ }^{169}$ However, on the liability of the master, it was the Committee's view that recklessness was not sufficient reason to deny immunity under the channelling provisions because it had been found by the courts that the master's actions did not cause the damage. ${ }^{170}$ At that point in time, appeal proceedings were pending before the Spanish Constitutional Court, but leave

ibid 69.

Ship and Bunker News Team, 'ICS Strongly Critises Spanish Supreme Court Decision in Prestige Oil Spill Case' (Ship Bunker EMEA News, 2 May 2016) < https://shipandbunker.com/news/emea/260768ics-strongly-criticises-spanish-supreme-court-decision-in-prestige-oil-spill-case $>$ accessed 23 June 2018. ibid.

Somers and Gonsaeles (n 77) 70.

IOPC Fund, 'Report on the Activities of the International Oil Pollution Compensation Funds in 2004' (2004) ch 9.

See $n 57$.

See $\mathrm{n} 78$.

IOPC Fund, Incidents Involving the IOPC Funds-1992 Fund 'Prestige-Judgment of Spanish Supreme Court' (31 August 2016) Agenda item IOPC/OCT16/3/2/1.

ibid 1.3 .

ibid 2.3.8.

ibid 3.4 . 
to appeal was subsequently denied. ${ }^{171}$ There may yet be a case brought by the master to the European Court of Human Rights (ECHR).

\section{CONCLUSIONS}

The 'Erika' and 'Prestige' disasters, along with the related case law, provide for an interesting case study on the application of the PPP. This deceptively simple principle sits in front of layers of complexity and has no clear or agreed definition. However, what can be identified in this examination of liability for marine oil pollution is that the PPP is developing and sometimes in different directions. At EU level, there is clearly an appetite to broaden the application of the principle to bring in responsible parties excluded by the international regime and to recognise that responsibility can also lie with exposing the marine environment to risk. In France and Spain, we see a similar pattern in exposing more responsible parties to liability but also the expansion of the principle to cover pure environmental damage. Alongside these developments, the international regime has also adopted a broader application of the principle over time, although it currently remains resistant to change on the channelling of liability, limits and compensation for pure environmental damage.

In the discrete but global sphere of marine oil pollution law it is also possible to see potential for influence across jurisdictions in the way the PPP finds its form and legal effect. Although rejected, it is interesting to note the suggestion in the Court of Justice of applying the 'user pays principle' and extending liability to the public. This approach concords with the position of the international regime. Also, if similar questions of supplementary liability were to be raised today, in the light of the specific exclusion of accidental oil pollution incidents covered by the international regime from the subsequently adopted Environmental Liability Directive, ${ }^{172}$ would the outcome be similar? There is a clear message from the Directive that supplementary liability is not to be considered. ${ }^{173}$ The decisions of the Cour de Cassation and the Spanish Supreme Court, on the other hand, suggest that liability can be effectively extended to other polluting parties within the confines of international obligations. The decisions appear to sweep aside the traditional assumptions of near unbreakable limits on liability and strict channelling of liability and open the door for liability to be extended to other parties including classification societies and insurers who cross the recklessness threshold. However, this may yet be subject to challenge in the ECHR.

The firm stance of the international regime on environmental damage per se was only formalised in $1984^{174}$ after a claim to the IOPC funds from the USSR for damage to the marine environment from an oil spill from the tanker 'Antonio Gramsci' based on a mathematical model prescribed by national legislation. The 1984 Protocol did not actually come into force until 1996 and, in the meantime, there were several other claims for damage to the marine environment per se which were

171 IOPC Fund, Incidents Involving the IOPC Funds-1992 Fund 'Prestige' (2 March 2017) Agenda item IOPC/APR17/3/2.

172 The Environmental Liability Directive (n 24).

173 ibid, art 2 and Annex IV(a).

174 IOPC Fund Assembly Resolution No 3 of 10 October 1980 (FUND/A/ES. 1/13, para 11.a and Annex I) formalised in the 1984 Protocol to the Civil Liability Convention art 2.3. 
allowed by Italian Courts. ${ }^{175}$ At the current time, the position of the international regime remains firm on the question of pure environmental damage. However, given the acceptance of natural resource damage under the US Oil Pollution Act ${ }^{176}$ and the EU Environmental Liability Directive, ${ }^{177}$ which largely follows the USA on natural resource damage there is continued pressure for change. ${ }^{178}$

What this examination also reveals is the tangible problems in identifying the 'polluter' in complicated global transactions. In the case of both vessels, there was a complex web of ownership with potentially responsible parties sheltering behind shell companies. The discussion above also identifies a potential danger that, in side-lining the traditional liability provisions in the international conventions, some parties may be over paying, whilst those who are implicated by the virtue of being end users of the product escape any contribution to the cost of remedying damage when disaster strikes. Ultimately, Total bore all the additional costs of the clean-up in the Commune de Mesquer flowing from the 'Erika' disaster, although they had paid their contribution to the international fund, and the State was fully compensated. It is also important to bear in mind that, although firmly entrenched in EU law, the PPP is not as fully embraced at an international level. Furthermore, the international liability regime, currently in place, operates in a very different legal sphere, with its own traditions and norms. Crucially, it provides an arrangement that strikes a compromise position between the interests of powerful global players and the protection and remediation of the environment. It should also be remembered that the prolonged period of legal repercussions surrounding liability, which followed the 'Erika' and 'Prestige' pollution incidents is unusual. Most claims are settled under the international conventions fully and without recourse to the courts. It is only in the most devastating of pollution incidents, that the fund has, in the past, not been able to meet the full costs of damage and since then, levels of liability have been extended.

In an ideal world, the law would ensure that there are adequate resources to repair any level of damage sustained and provide full compensation for damage to both legal persons and the environment. In such a world, there would be no compromise where the environment is concerned and every party responsible would pay their fair share of liability flowing from a pollution incident. There would also be no escaping liability through complex ownership arrangements and the use of 'shell' companies. In the meantime, it has been some time since a major incident of this sort hit the headlines and the full introduction of double hulled vessels may mean that there will be fewer in the future. ${ }^{179}$ Calls for changes to the international regime have, to a degree, subsided as have fears that its future is in jeopardy.

'Patmos' 1985 and 'Haven' 1991; Louise de La Fayette, 'New Approaches for Addressing Damage to the Marine Environment' (2005) 20 Int'l J Mar Coastal L 167, 182.

176 US Oil Pollution Act (n 42).

177 The Environmental Liability Directive (n 24).

178 MacAllister, Elliott and Partners Ltd, 'Study on the Valuation and Restoration of Damage to Natural Resources for the Purpose of Environmental Liability' (2001) European Commission, Doc B4-3040/ 2000/265781/MAR/B3; Frank Cross 'Natural Resource Damage Valuation' (1989) 42 Vanderbilt LR 334; de La Fayette (n 175).

179 Ship Structure Committee, 'Prestige: Complete Hull Failure in a Single-hull Tanker' (no date). This case study suggests that these arguments are based on a misunderstanding of the rules, which require the same strength from both single and double-hulled ships. 
At present, the PPP cannot be perceived as a high level transnational norm. However, as we see from the case law flowing from the 'Erika' and 'Prestige' disasters, the courts can serve to foster legal innovation and play a role in providing the link between outcomes and concrete rules. ${ }^{180}$ They form an important part of creating a legal history for the PPP and in so doing contribute to the formation of a legal identity for the principle. Furthermore, through this examination of the international regime and the case law, it is possible to identify cross-fertilisation between jurisdictions and levels of governance as the PPP develops in discrete legal settings. ${ }^{181}$

180 Ben Boer, 'Implementation of International Sustainability Imperatives at a National Level' in PJIM Waart and others (eds), Sustainable Development and Good Governance (Martinus Nijhoff 1995) 117, 118; Jonathan Verschuuren, 'Sustainable Development and the Nature of Environmental Legal Principles' (2006) 9 Potchefstroom Electronic LJ 17. Scotford (n 1). 